\title{
A Unique Role for Kv3 Voltage-Gated Potassium Channels in Starburst Amacrine Cell Signaling in Mouse Retina
}

\author{
Ander Ozaita, ${ }^{1,2 *}$ Jerome Petit-Jacques, ${ }^{1,2,3 *}$ Béla Völgyi, ${ }^{1,3 *}$ Chi Shun Ho, ${ }^{4}$ Rolf H. Joho, ${ }^{4}$ Stewart A. Bloomfield, ${ }^{1,3}$ and \\ Bernardo Rudy ${ }^{1,2}$ \\ Departments of ${ }^{1}$ Physiology and Neuroscience, ${ }^{2}$ Biochemistry, and ${ }^{3}$ Ophthalmology, New York University School of Medicine, New York, New York 10016, \\ and ${ }^{4}$ Center for Basic Neuroscience, The University of Texas Southwestern Medical Center, Dallas, Texas 75390-9111
}

Direction-selective retinal ganglion cells show an increased activity evoked by light stimuli moving in the preferred direction. This selectivity is governed by direction-selective inhibition from starburst amacrine cells occurring during stimulus movement in the opposite or null direction. To understand the intrinsic membrane properties of starburst cells responsible for direction-selective GABA release, we performed whole-cell recordings from starburst cells in mouse retina. Voltage-clamp recordings revealed prominent voltagedependent $\mathrm{K}^{+}$currents. The currents were mostly blocked by $1 \mathrm{~mm}$ TEA, activated rapidly at voltages more positive than $-20 \mathrm{mV}$, and deactivated quickly, properties reminiscent of the currents carried by the Kv3 subfamily of $\mathrm{K}^{+}$channels. Immunoblots confirmed the presence of Kv3.1 and Kv3.2 proteins in retina and immunohistochemistry revealed their expression in starburst cell somata and dendrites. The Kv3-like current in starburst cells was absent in Kv3.1-Kv3.2 knock-out mice. Current-clamp recordings showed that the fast activation of the Kv3 channels provides a voltage-dependent shunt that limits depolarization of the soma to potentials more positive than $-20 \mathrm{mV}$. This provides a mechanism likely to contribute to the electrical isolation of individual starburst cell dendrites, a property thought essential for direction selectivity. This function of Kv3 channels differs from that in other neurons where they facilitate highfrequency repetitive firing. Moreover, we found a gradient in the intensity of Kv3.1b immunolabeling favoring proximal regions of starburst cells. We hypothesize that this $\mathrm{Kv} 3$ channel gradient contributes to the preference for centrifugal signal flow in dendrites underlying direction-selective GABA release from starburst amacrine cells

Key words: retina; direction selectivity; potassium channels; amacrine cells; GABAergic; inhibition

\section{Introduction}

As first described by Barlow and colleagues (Barlow et al., 1964; Barlow and Levick, 1965), direction-selective (DS) ganglion cells in retina respond vigorously to stimulus movement in the preferred direction yet show little or no activity in response to movement in the opposite or null direction. Subsequent studies showed that GABAergic antagonists abolish direction selectivity, suggesting that asymmetric inhibition resulting from null direction stimulus movement plays a crucial role (Barlow and Levick, 1965; Wyatt and Daw, 1976; Caldwell et al., 1978; Ariel and Daw, 1982; Kittila and Massey, 1995). Starburst amacrine cells, interneurons that release both acetylcholine and GABA, synapse onto DS cells and thus have been a favorite candidate for the source of GABAergic inhibition responsible for direction selectivity (Vaney et al., 1989; Famiglietti, 1991, 1992). However, although cholinergic excitation of DS cells by starburst cells was observed

Received April 5, 2004; revised July 6, 2004; accepted July 7, 2004.

This work was supported by National Institutes of Health Grants NS30989 (B.R.), NS045217 (B.R.), and EY07360 (S.A.B.), National Science Foundation Grant IBN-0078297 (B.R.), a fellowship from the American Heart Association Heritage Affiliate (A.O.), and an unrestricted grant from Research to Prevent Blindness (S.A.B.).

${ }^{*}$ A.O., J.P.-J., and B.V. contributed equally to this work.

Correspondence should be addressed to Dr. Bernardo Rudy, Department of Physiology and Neuroscience, New York University School of Medicine, 550 First Avenue, New York, NY 10016. E-mail: rudyb01@med.nyu.edu. DOI:10.1523/JNEUROSCI.1275-04.2004

Copyright $\odot 2004$ Society for Neuroscience $\quad$ 0270-6474/04/247335-09\$15.00/0
(Masland and Ames, 1976; Masland and Mills, 1979), it was unclear whether these cells also produced the GABAergic null inhibition.

Recent studies provide compelling evidence that starburst cells indeed play a key role in the generation of direction selectivity. Specific elimination of starburst cells, either through pharmacological manipulation or genetic targeting, abolishes the selectivity of DS cells (Yoshida et al., 2001; Amthor et al., 2002; but see He and Masland, 1997). Based on dual patch recordings, Fried et al. (2002) showed that starburst cells provide direct inhibition to DS cells. Moreover, they found synaptic asymmetry, whereby starburst cells laying on the null side of a DS cell provide inhibition, whereas those on the preferred side do not. In addition, the null inhibition from starburst cells was itself direction selective, being stronger for stimulus movement in the null direction.

Imaging of $\mathrm{Ca}^{2+}$ signals generated in starburst cell processes during visual stimulation (Euler et al., 2002) demonstrated that individual dendritic branches act independently, confirming a previous computational model (Miller and Bloomfield, 1983). In addition, the $\mathrm{Ca}^{2+}$ signals within each branch showed selectivity for stimuli moving centrifugally from the soma. The membrane potential changes underlying these direction-selective increases in $\mathrm{Ca}^{2+}$ concentration are likely to produce the directionselective GABA release described by Fried et al. (2002).

These data suggest that the direction-selective properties of 
starburst cells arise from intrinsic mechanisms likely to include both passive and active membrane properties (Poznanski, 1992; Velte and Miller, 1997; Euler et al., 2002). However, the specific ion channels present in starburst cells are essentially unknown. Identification of these channels is timely, because genetic manipulations can now be used to study their role in starburst cell signaling. As the most diverse group of ion channels, potassium channels play key roles in modulating the electrical properties of neurons. We therefore investigated the specific $\mathrm{K}^{+}$channels present in starburst cells in the mouse retina using a combined electrophysiological, immunohistochemical, and genetic approach. We show that starburst cells have large voltagedependent $\mathrm{K}^{+}$currents mediated primarily by voltage-gated $\mathrm{K}^{+}$ channels containing subunits of the Kv3 subfamily. Furthermore, our results suggest a mechanism by which the $\mathrm{Kv} 3 \mathrm{~K}^{+}$channels may underlie the electrical independence of individual starburst cell dendrites as well as the preference for centrifugal signal propagation.

\section{Materials and Methods}

Retinal preparation for electrophysiological recording. Kv3.1-Kv3.2 double knock-out (DKO) mice in ICR background were generated by crossing Kv3.1 $1^{+/-}$mice (Ho et al., 1997) with Kv3.2 ${ }^{+/-}$mice (Lau et al., 2000). The genotype of the mice was determined using genomic tail DNA. The absence of Kv3.1 and Kv3.2 protein in knock-out (KO) animals was confirmed in immunoblots of brain membrane extracts. All animal procedures complied with National Institutes of Health guidelines for the ethical use of animals. ICR wild-type (WT) and DKO mice (20-60 d of age) were deeply anesthetized with an intraperitoneal injection of pentobarbital $(0.08 \mathrm{gm} / \mathrm{gm}$ body weight $)$. Lidocaine hydrochloride $(20 \mathrm{mg} / \mathrm{ml})$ was applied locally to the eyelids and surrounding tissue. A flattened retinal-scleral eyecup preparation developed for rabbit by $\mathrm{Hu}$ et al. (2000) was adopted and modified for mouse. Briefly, the eye was removed under dim red illumination and hemisected anterior to the ora serrata. Animals were killed immediately after enucleation by cervical dislocation. The lens and vitreous humor were removed and, the resultant eyecup preparation was placed on the base of a submersion-type recording chamber. Several radial incisions were made peripherally, and the retina was flattened in the chamber vitreal side up. The chamber was mounted on a microscope stage within a Faraday cage and superfused (1-2 $\mathrm{ml} / \mathrm{min})$ with an oxygenated mammalian Ringer's solution composed of the following (in $\mathrm{mm}$ ): $120 \mathrm{NaCl}, 5 \mathrm{KCl}, 25 \mathrm{NaHCO}_{3}, 0.8$ $\mathrm{Na}_{2} \mathrm{HPO}_{4}, 0.1 \mathrm{NaH}_{2} \mathrm{PO}_{4}, 1 \mathrm{MgSO}_{4}, 2 \mathrm{CaCl}_{2}, 10$ D-glucose 10. A pH of 7.4 was maintained by bubbling with $95 \% \mathrm{O}_{2}-5 \% \mathrm{CO}_{2}$ at room temperature of $20-22^{\circ} \mathrm{C}$.

Electrophysiological recordings. Recordings were made in the whole-cell patch mode with an Axopatch 200B amplifier (Axon Instruments, Burlingame, CA). Cells were visualized with near infrared light $(>775 \mathrm{~nm})$ at $80 \times$ magnification with a Nuvicon tube camera (Dage-MTI, Michigan City, IN) and differential interference optics on a fixed stage microscope (BX51WI; Olympus, Tokyo, Japan). Currents were recorded under voltage clamp, filtered at $1 \mathrm{kHz}$, sampled at $20 \mathrm{kHz}$, and stored directly on the hard drive of the computer using a Digidata 1200 analog-to-digital interface (Axon Instruments). For the characterization of voltage responses, neurons were recorded in the fast current-clamp mode of the amplifier. Neurons were held at $-70 \mathrm{mV}$ with small injections of direct current. pClamp (version 8.02; Axon Instruments) was used for data acquisition with data analysis performed off-line using Minianalysis (version 6.0.1; Synaptosoft, Decatur, GA) and Origin (version 6.1; OriginLab, Northampton, MA) software packages.

Patch electrodes (3-5 M $\Omega$ ) were pulled from standard wall borosilicate glass tubing (World Precision Instruments, Sarasota, FL) with a Flaming/Brown type micropipette puller (Sutter Instruments, Novato, CA). Pipettes were filled with a K-gluconate internal solution composed of the following (in mM): $144 \mathrm{~K}$-gluconate, $3 \mathrm{MgCl}_{2}, 0.2 \mathrm{EGTA}, 10$ HEPES, 4 ATP-Mg, 0.5 GTP-Tris, pH 7.3, with $\mathrm{KOH}$, and biocytin $(0.2 \%$ w/v; Sigma, St. Louis, MO).
Labeling of biocytin-filled neurons. Neurons were labeled by allowing biocytin to diffuse from the micropipette during patch recordings. After the electrophysiological experiments were completed, the retina was fixed in a cold $\left(4^{\circ} \mathrm{C}\right)$ solution of $4 \%$ paraformaldehyde in $0.1 \mathrm{~m}$ phosphate buffer (PB), pH 7.3, overnight. Retinas were then washed in phosphate buffer and soaked in a solution of $0.18 \%$ hydrogen peroxide in methyl alcohol for $1 \mathrm{hr}$. This treatment completely abolished the endogenous peroxidase background activity. Retinas were then washed in phosphate buffer and reacted with the Elite ABC kit (Vector Laboratories, Burlingame, CA) and 1\% Triton X-100 in sodium PBS (9\% saline, pH 7.5). Retinas were subsequently processed for peroxidase histochemistry using $3,3^{\prime}$-diaminobenzidine $(\mathrm{DAB})$ as the chromogen. Retinas were then dehydrated and flat-mounted for light microscopy.

Immunohistochemistry. Mice were anesthetized as described above. After enucleation, the retina eyecup was isolated from the anterior parts of the eye and placed in freshly prepared $4 \%$ paraformaldehyde in $0.1 \mathrm{M}$ $\mathrm{PB}, \mathrm{pH} 7.3$, for $30 \mathrm{~min}$. Animals were killed immediately after enucleation by cervical dislocation. For sectioning, retinas were cryoprotected in $30 \%$ sucrose in PB. Eyecups were embedded in Tissue-Tek (Pelco, Redding, CA), rapidly frozen and then cryosectioned (15 $\mu \mathrm{m})$, and thawmounted on gelatin-coated slides. Sectioned and whole-mounted preparations were preincubated for $1 \mathrm{hr}$ in $0.1 \mathrm{M} \mathrm{PB}$ containing 2\% normal goat serum (NGS), $0.4 \%$ Triton X-100, and $1 \%$ bovine serum albumin (BSA) at room temperature. Specimens were subsequently incubated overnight with primary antibodies diluted in $0.1 \mathrm{M} \mathrm{PB}$ containing $2 \%$ NGS, $0.4 \%$ Triton $\mathrm{X}-100$, and $1 \% \mathrm{BSA}$ at $4^{\circ} \mathrm{C}$. Negative controls, performed by omitting the primary antibody, never yielded staining patterns. The Kv3.2 antibody was derived by immunizing rabbits to a peptide sequence of the Kv3.2 protein located before the first membranespanning domain in the $\mathrm{N}$-terminal area. The Kv3.2 antibody recognizes all Kv3.2 isoforms (Chow et al., 1999). The Kv3.1b antibody was directed against the $\mathrm{C}$-terminal sequence of the predominant isoform of the Kv3.1 gene, Kv3.1b (Weiser et al., 1995). The Kv3.1a antibody was directed against the C-terminal sequence of the Kv3.1a isoform (Ozaita et al., 2002). Affinity-purified Kv3.2 antibody was used at 1:300 dilution, $\mathrm{Kv} 3.1 \mathrm{~b}$ antibody was used at 1:500 dilution, and Kv3.1a antibody was used at 1:200 dilution. The Vectastain Elite ABC kit (Vector Laboratories) was used to immunolabel via peroxidase histochemistry using DAB as the chromogen. For double labeling fluorescent microscopy, goat anticholine acetyltransferase (ChAT) (1:200; Chemicon, Temecula, CA), mouse anti-calretinin (1:100; Chemicon), or mouse anti-calbindin (1: 500; Sigma) antibodies were used along with one of the three Kv3 antibodies (see above). The tissue was then incubated with a combination of secondary antibodies consisting of cyanine 3 (Cy3)-conjugated goat antirabbit and Cy2-conjugated chicken anti-goat or Cy2-conjugated goat anti-mouse IgG (1:600; Jackson ImmunoResearch, West Grove, PA). Sections were then washed and coverslipped in Vectashield (Vector Laboratories). Images were acquired either with an Olympus CCD camera mounted on an Olympus AX-70 microscope or a Zeiss LSM 510 Meta confocal microscope (Zeiss, Thornwood, NY).

NIH Image software was used to quantify the intensity of immunolabeling in starburst cell dendrites. Individual immunolabeled segments of membrane were mapped digitally, and average intensity values (on a 0-255 scale) were computed for each. Segments were then placed into somatic or proximal, intermediate, or distal dendritic regions (cf. Famiglietti, 1983; Miller and Bloomfield, 1983), and values were then averaged within each region.

Western blot analysis. Western blots were prepared as described previously (Ozaita et al., 2002). Mouse brain and retinal membrane extracts were prepared from a P3 fraction of tissue homogenate in the presence of protease inhibitors (Hartshorne and Catterall, 1984) and solubilized in $1 \%$ SDS. The suspension was centrifuged at $30,000 \times g$ to remove nonsolubilized material, and the top two-thirds of the supernatant were used for additional experiments. Samples were loaded $(20 \mu \mathrm{g}$ per lane of mouse brain membrane fraction and $45 \mu \mathrm{g}$ per lane of mouse retinal membrane) on a $10 \%$ SDS-acrylamide gel for electrophoresis and then transferred onto nitrocellulose membranes (Bio-Rad, Hercules, CA). Membranes were blocked for $1 \mathrm{hr}$ at room temperature in blocking solution (5\% dry milk, $0.1 \%$ Tween $20,1 \%$ BSA in PBS) and incubated 
overnight with primary antibodies diluted in blocking solution. The membranes were incubated with either Kv3.1b antibody at 1:1000 to 1:2000 dilution, Kv3.1a antibody at 1:500 dilution, or Kv3.2 antibody at 1:500 dilution. After thorough washing with PBS, membranes were incubated with horseradish peroxidase-conjugated donkey anti-rabbit antibodies (1:5000; Amersham Biosciences, Piscataway, NJ) in blocking solution for $1 \mathrm{hr}$ at room temperature and rinsed in PBS afterward. Immunolabels were detected using an enhanced chemiluminescence detection kit (Pierce Chemical, Woburn, MA).

Isolated retinas were homogenized in a buffer containing $320 \mathrm{~mm}$ sucrose, $4 \mathrm{~mm}$ HEPES, and a mixture of different protease inhibitors $(1 \times$ Complete; Roche, Indianapolis, IN). The homogenate was centrifuged, the supernatant was collected, and the pellet was resuspended in homogenization buffer. Both fractions were then pooled.

Statistical analyses. Data were analyzed using Student's $t$ test statistic. Presentation of data is in the form of mean \pm SEM throughout.

\section{Results}

Prominent Kv3-like $\mathrm{K}^{+}$currents in starburst amacrine cells

The whole-cell patch-clamp technique was used to characterize the $\mathrm{K}^{+}$currents in starburst amacrine cells in the mouse retina. We chose to study starburst cells in the mouse retina rather than in the rabbit, where they have been extensively studied, with the goal of using transgenic models. To record from starburst-b cells [on-center starburst cells with somata displaced to the ganglion cell layer (GCL) and dendrites ramifying in sublamina b of the inner plexiform layer (IPL)], we targeted round-shaped neuronal somata with relatively small diameters $(5-10 \mu \mathrm{m})$ in the GCL. After electrophysiological analyses, all cells were filled with biocytin to characterize the morphology of the cells by post hoc histology. Starburst amacrine cells in the mouse showed the typical, symmetric dendritic morphology described in other mammals (Famiglietti, 1983; Tauchi and Masland, 1984; Bloomfield and Miller, 1986). This included four to five primary dendrites that first branched into thin, wavy, intermediate segments that then divided into a dense plexus of distal branches showing numerous varicosities (Fig. 1C). Although it remains controversial as to whether starburst amacrine cells can support spike activity, starburst cells under our recording conditions showed no spontaneous or evoked spiking, consistent with previous patch-clamp studies in other species (Taylor and Wässle, 1995; Peters and Masland, 1996) (Fig. 1A). It should be noted that the small transient component seen at the onset of depolarizing pulses could not be blocked by TTX. In contrast, neighboring ganglion cells with large cell bodies showed robust spike activity when depolarized with extrinsic current (Fig. $1 B$ ).

Starburst cells displayed strong inward rectification (Fig. 1A), presumably because of the presence of inward rectifier potassium currents. In addition, the level of depolarization in response to current injections of increasing magnitude tended to saturate, so that it was very difficult to depolarize the cells to membrane potentials more positive than $-20 \mathrm{mV}$ (Fig. 1A). This suggests the activation of large currents at depolarized voltages that effectively shunt the cell and limit depolarization in response to current injection. A large decrease in membrane resistance is also reflected in the shorter time constant of the onset of depolarizations generated during large, positive current injections.

Under voltage clamp, starburst cells generated large outward currents during membrane depolarization (Fig. 2A). These currents activated rapidly at membrane potentials more positive than $-20 \mathrm{mV}(\tau=2.65 \pm 0.25 \mathrm{msec}$ at $0 \mathrm{mV} ; n=9)$ and inactivated little during depolarizing pulses with duration of 300 msec (Fig. 2A). They also deactivated very quickly $(\tau=3.00 \pm$ $0.27 \mathrm{msec}$ at $-40 \mathrm{mV} ; n=9$ ) (Fig. $2 B, D$ ). These properties are reminiscent of the currents carried by channels of the Kv3 sub-
A
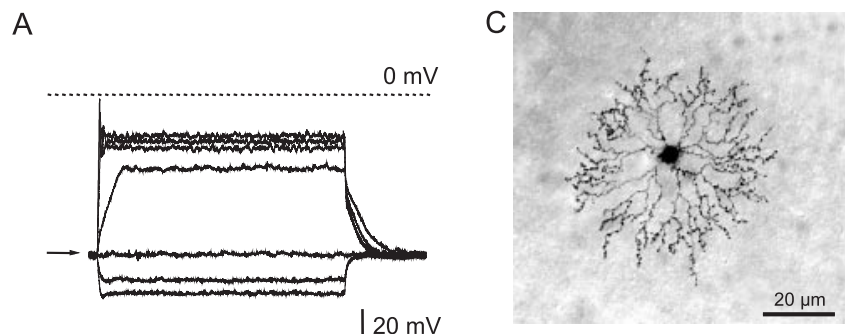

B
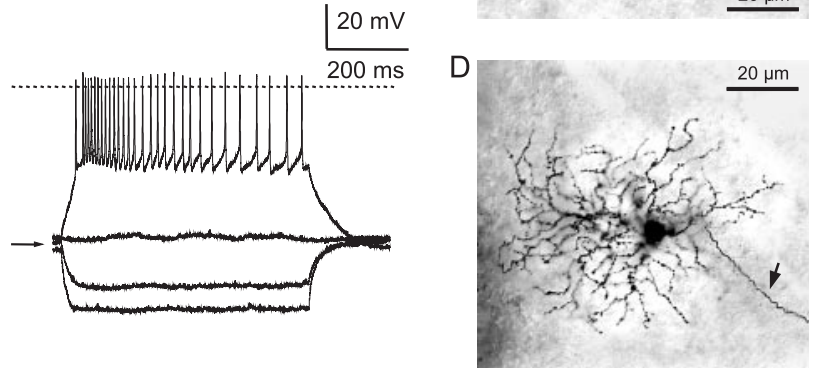

Figure 1. Representative current-clamp recordings from a starburst amacrine cell and a ganglion cell in the mouse retina. $A$, Steps of current were injected in a starburst amacrine cell for $600 \mathrm{msec}$, and the resulting voltage responses were recorded under whole-cell patch clamp. Between pulses, the cell was maintained at a voltage of $-70 \mathrm{mV}$ by constant injection of a small amount of current (indicated by the arrow at the left of the traces). The voltage traces shown are in response to injection of current pulses of $-100,-50,0,+50,+200,+300$, and $+400 \mathrm{pA}$. Note the near saturation of the membrane depolarization for current pulses greater than +50 $\mathrm{pA}$. The dotted line represents $0 \mathrm{mV}$. $B$, A ganglion cell was maintained at $-70 \mathrm{mV}$, and voltage membrane recordings are shown in response to current injections of $-100,-50,0$, and +50 pA. The last step reached spike threshold and produced robust repetitive firing. C, Visualization of the starburst amacrine cell illustrated in $A$ after injection with biocytin. Note the characteristic dendritic arborization of the starburst amacrine cell. The cell was reconstructed from images taken at different depths using Adobe Photoshop (Adobe Systems, San Jose, CA). D, Reconstruction of the ganglion cell recorded in $B$ after injection with biocytin. Note the presence of the axon (arrow).

family (Rudy et al., 1999; Rudy and McBain, 2001). Potassium channels containing pore-forming subunits of this subfamily (Kv3 channels) activate rapidly during large membrane depolarizations (positive to $-20 \mathrm{mV}$ ) and deactivate very quickly after membrane repolarization. They are thought to be specialized for fast action potential repolarization without compromising the probability of spike generation (for review, see Rudy et al., 1999; Rudy and McBain, 2001).

$\mathrm{Kv} 3$ channels can be distinguished from most other $\mathrm{K}^{+}$channels by their high sensitivity to low concentrations of external TEA. Application of $1 \mathrm{~mm}$ TEA blocks $>80 \%$ of Kv3 currents, a concentration that affects few other $\mathrm{K}^{+}$channels (Erisir et al., 1999; Rudy et al., 1999). We found that $1 \mathrm{~mm}$ TEA blocked a large percentage (75-80\%) of the outward current in starburst amacrine cells (Fig. $2 A, E$ ). The outward currents that survived application of $1 \mathrm{~mm}$ TEA deactivated much more slowly than the total or the TEA-sensitive currents $(\tau=8.17 \pm 2.7 \mathrm{msec} ; n=3)$, indicating that they were generated by $\mathrm{K}^{+}$channels different from Kv3 (Fig. 2A, C,D).

These results suggest that most of the $\mathrm{K}^{+}$current in starburst amacrine cells in the mouse retina is carried by channels of the Kv3 subfamily. There are four Kv3 genes reported in mammals, three of which (Kv3.1-Kv3.3) are prominently expressed in several CNS structures (Weiser et al., 1994). Products of the Kv3.1 and Kv3.2 genes express delayed rectifier-type $\mathrm{K}^{+}$currents, whereas Kv3.3 and Kv3.4 proteins express inactivating, A-type $\mathrm{K}^{+}$currents (Rudy et al., 1999). Our finding that the $\mathrm{K}^{+}$current in starburst cells shows little inactivation suggests that it is mediated by channels that contain Kv3.1 and/or Kv3.2 proteins. 


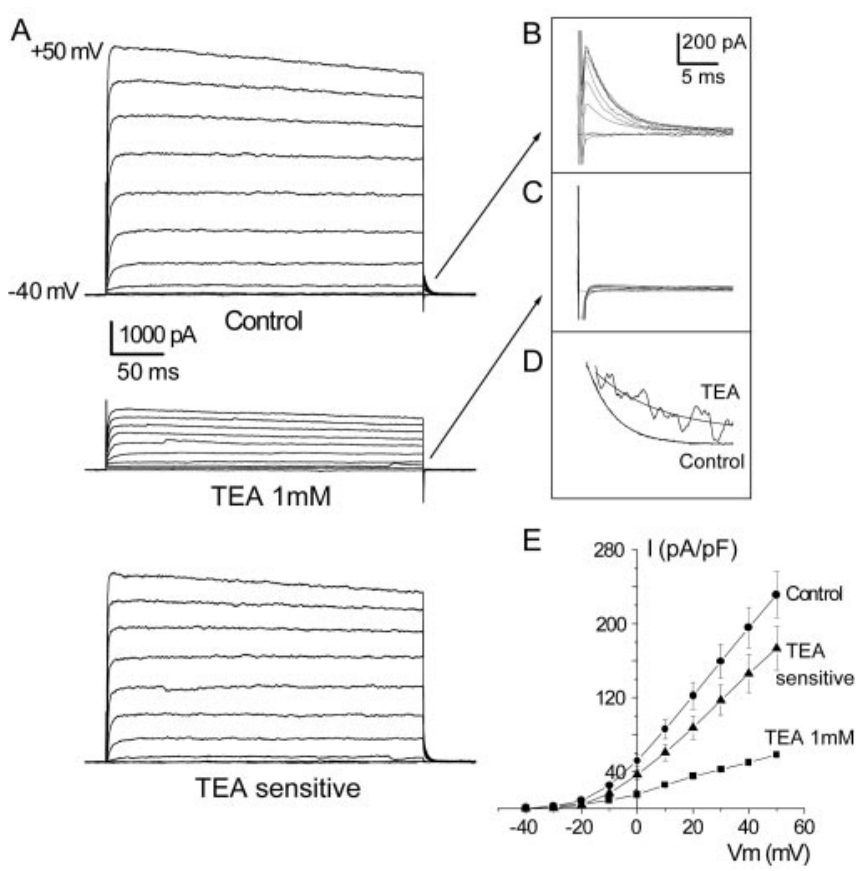

Figure 2. Large Kv3-like currents in starburst amacrine cells of the mouse retina. A, A starburst amacrine cell was clamped at a holding potential of $-40 \mathrm{mV}$, and voltage steps between -40 and $+50 \mathrm{mV}$ were applied in $10 \mathrm{mV}$ increments. Resulting membrane currents are shown in control solution (top panel) and in the presence of $1 \mathrm{~mm}$ TEA (middle panel). Note the strong inhibition of the outward currents in the presence of TEA. The current traces obtained in TEA were subtracted from the control traces to obtain the TEA-sensitive component (bottom panel). $B, C$, Faster time scale illustrating the current tails recorded after termination of test depolarizations before $(B)$ and during $(C)$ TEA application. Note the fast current tails characteristic of Kv3-like currents and their absence in the presence of TEA. D, Tail currents recorded during the return from +40 to $-40 \mathrm{mV}$ in control solution and in the presence of TEA. The current trace in TEA was normalized to the peak value of the control current. Traces were fitted with a single exponential decay function to obtain time constants; averaged values are provided in the text. The tail current in TEA deactivated more slowly than in control solution. E, Relationship between average outward current density and membrane potential in the presence and absence of TEA. Data are from 10 starburst amacrine cells. Vertical bars represent SEM.

The presence of large Kv3 currents in starburst cells was somewhat surprising, because these channels have been described only in spiking neurons where they are thought to have important roles in producing fast-spike repolarization. They are preferentially found in neurons that fire sustained trains of action potentials at high frequency or that can follow high-frequency stimuli (Wang et al., 1998; Rudy et al., 1999; Rudy and McBain 2001). To confirm that most of the outward current in starburst amacrine cells was mediated by Kv3 channels, we explored the expression of $\mathrm{Kv} 3$ proteins in the mouse retina.

\section{Expression of $K v 3.1$ and $K v 3.2$ proteins in mouse retina}

Immunoblot analysis was used first to investigate whether Kv3 proteins are expressed in the mouse retina. Kv3.1a, Kv3.1b, and Kv3.2 antibodies recognized, in immunoblots of extracts from mouse retina, single bands with sizes similar to those seen in whole brain extracts (Fig. 3). In contrast, we could not detect Kv3.3 or Kv3.4 proteins in the retina (data not shown). This pattern is similar to that seen in several brain areas, such as in the neocortex and hippocampus, where both Kv3.1 and Kv3.2 proteins are expressed in the same neuronal populations, probably as subunits of heteromeric channel complexes (Chow et al., 1999).

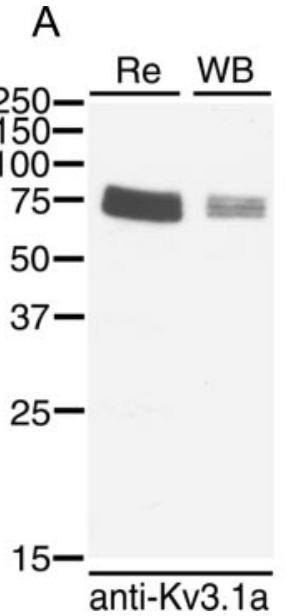

B

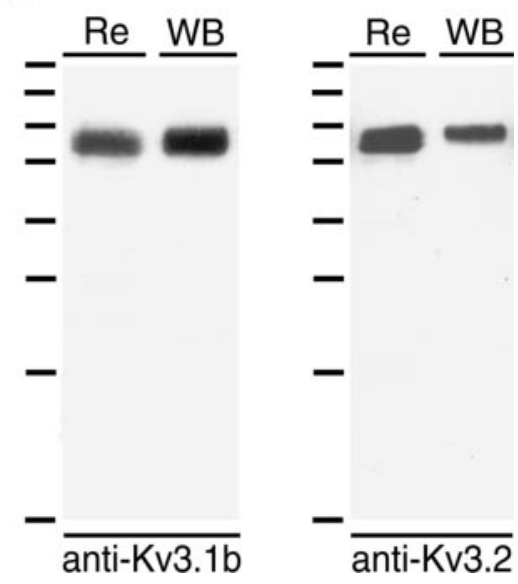

Figure 3. Kv3 proteins are expressed in the retina. Western blot analysis of membrane extracts of mouse retina (Re) and mouse whole brain (WB) with anti-Kv3.1a (A), Kv3.1b (B), and Kv3.2 ( $C$ antibodies. All three antibodies detected unique bands of similar molecular weights in both tissues. Membrane protein samples of retina ( $45 \mu \mathrm{g}$ per lane) and whole brain (20 $\mu \mathrm{g}$ per lane) were separated by SDS-PAGE and transferred to nitrocellulose membranes that were later incubated with antibodies. Molecular weight (in kilodaltons) standards were run in parallel and are indicated at the left.

\section{Cellular and subcellular localization of Kv3.1 and Kv3.2 proteins} in the retina

Immunohistochemistry of sections from mouse retina was performed to determine which structures express Kv3.1a, Kv3.1b, and Kv3.2 proteins. The most prominent staining with all three antibodies was seen in the proximal layers of the retina (Fig. 4). Both Kv3.1b (Fig. 4B) and Kv3.2 (Fig. 4C) antibodies stained relatively small somata (filled arrowheads) in the proximal margin of the inner nuclear layer (INL), close to the border with the IPL, as well as in the GCL. In both layers, the staining of these cells was stronger with Kv3.1b than Kv3.2 antibodies. As in brain (Weiser et al., 1995; Du et al., 1996; Chow et al., 1999; Tansey et al., 2002), the Kv3.1b- and Kv3.2-stained cell bodies had a distinct ring-like appearance indicative of protein expression predominantly at or near the plasma membrane. Based on their size and location, the small labeled cells likely correspond to amacrine and displaced amacrine cells in the INL and GCL, respectively. In addition, a few scattered ganglion cells, identified by their relatively large somata and thick proximal dendrites, were also stained with Kv3.1b and Kv3.2 antibodies in the GCL (Fig. 4B, C, arrows). However, it is clear that the majority of ganglion cells were not stained for either Kv3.1b or Kv3.2.

There was also prominent Kv3.1b staining in strata 2 and 4 of the IPL (Fig. $4 B$, open arrowheads), which represent the layers where the dendrites of starburst-a and starburst-b cells ramify (Famiglietti, 1983; Bloomfield and Miller, 1986), suggesting expression of this channel protein in starburst cell dendritic processes. Kv3.2 antibodies produced a similar, albeit weak, labeling pattern in the IPL (Fig. 4C).

In the brain, the Kv3.1a protein is frequently coexpressed with the Kv3.1b isoform in the same neuronal populations, but the $\mathrm{Kv} 3.1 \mathrm{a}$ protein is concentrated in axonal processes, with only weak somatic staining (Ozaita et al., 2002). In neurons in which dendritic processes participate in dendrodendritic synapses, such as in mitral cells of the olfactory bulb, the Kv3.1 a protein is prominent in dendritic membranes (Ozaita et al., 2002). A similar pattern was seen in the retina, where Kv3.1a antibodies labeled 


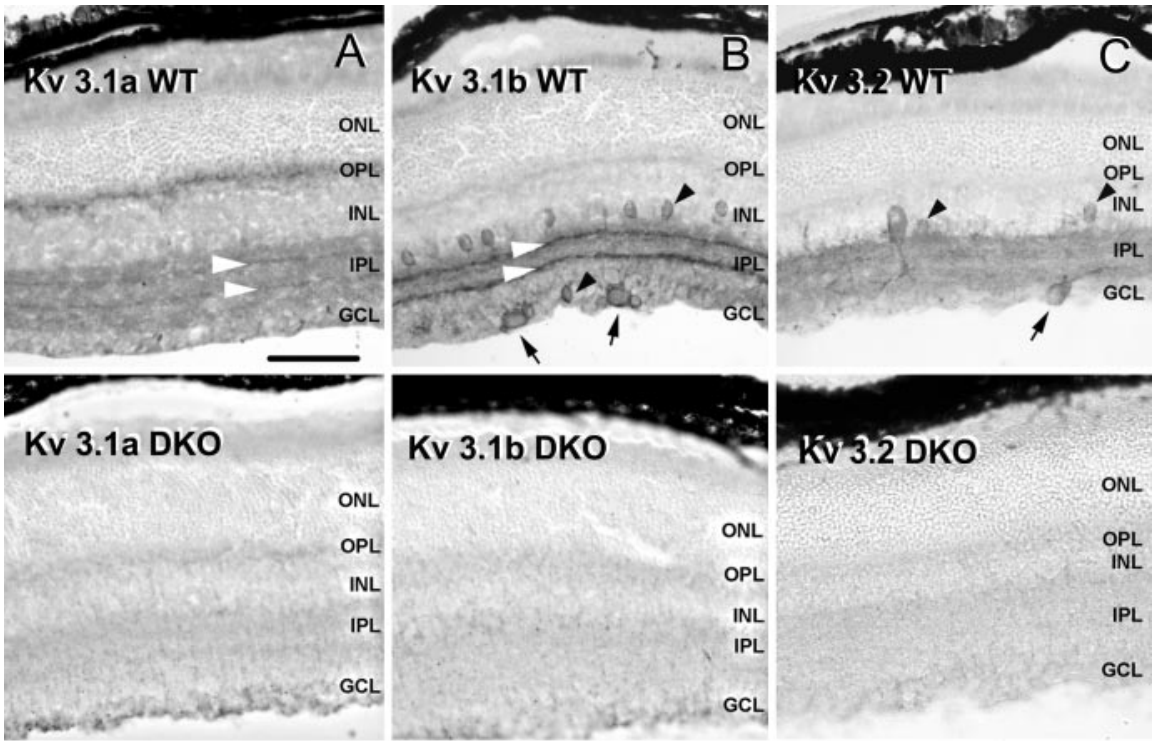

Figure 4. Immunolocalization of Kv3.1 and Kv3.2 proteins in the mouse retina. A, Kv3.1a immunostaining obtained on transversal sections of WT (top panel) and Kv3.1-3.2 DKO (bottom panel) mouse retina. B, Kv3.1b immunoreactivity in sections of WT (top panel) and DKO mouse (bottom panel). C, Kv3.2 immunolabeling in sections of WT (top panel) and DKO (bottom panel) animals. The staining observed in WT mice is absent in the retinas from DKO mice, indicating that the antibodies recognize their specified targets. Note the immunostaining for Kv3.1a and Kv3.1b in strata 2 and 4 of the IPL (open arrowheads). There is also prominent staining with Kv3.1b (but not with Kv3.1a antibodies) of small cell bodies, presumably starburst amacrine cells, in the inner margin of the INL and in the GCL. The Kv3.2 antibodies also faintly label presumed starburst cell bodies as well (C, filled arrowheads). There is also staining of some ganglion cells in the $\mathrm{GCL}$ (arrows) with Kv3.1b and Kv3.2 antibodies (B, $C$ ). Scale bar, $50 \mu \mathrm{m}$. ONL, Outer nuclear layer; OPL, outer plexiform layer.
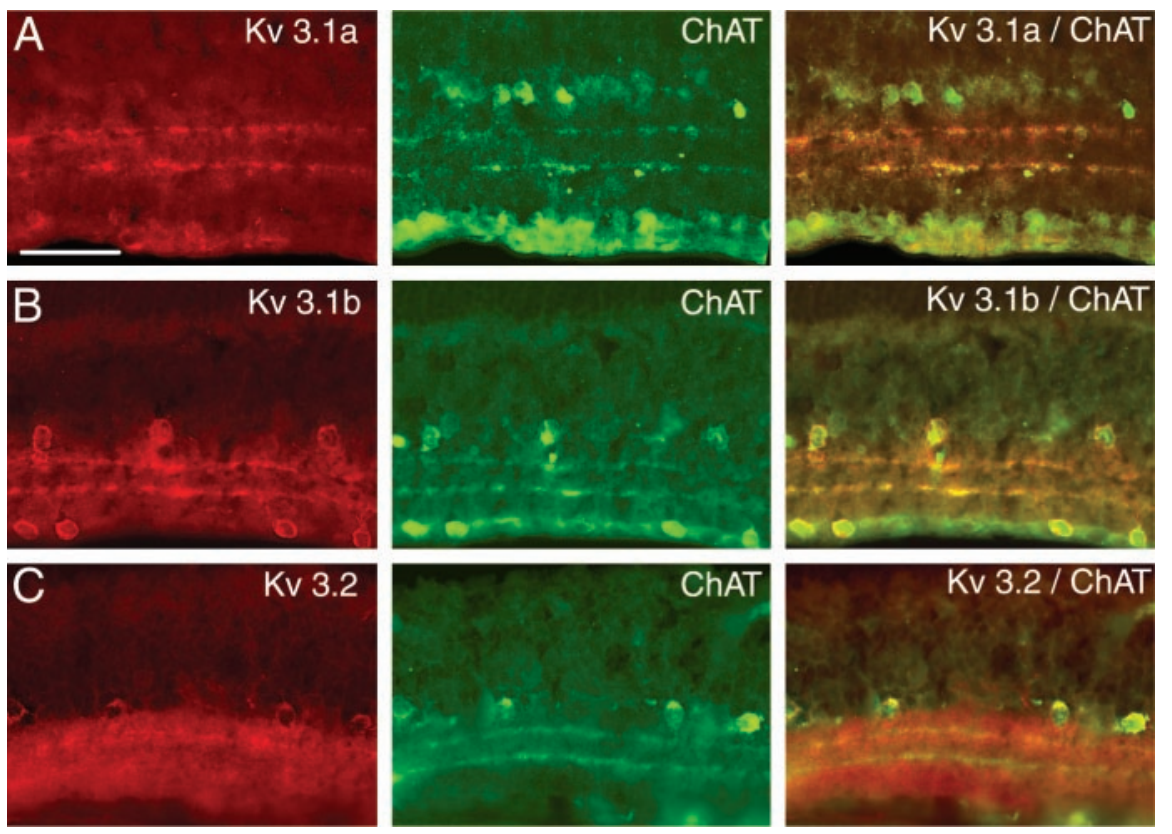

Figure 5. Colocalization of Kv3.1a, Kv3.1b, and Kv3.2 with ChAT in starburst amacrine cells. A, Kv3.1a primarily stains processes associated with strata 2 and 4 in the IPL. Those processes correspond to starburst cell dendrites, as determined by double labeling with the cholinergic marker ChAT. B, Kv3.1b labels the processes of the starburst cells in the IPL as well as their cell bodies located in both the INL and GCL, as demonstrated by double staining with ChAT. C, Kv3.2 produces a fainter staining of starburst cell somata and processes and stronger staining of the neuropil in the IPL than Kv3.1a and Kv3.1b antibodies. Scale bar, $30 \mu \mathrm{m}$.

starburst cell dendrites but produced little to no staining of cell bodies (Fig. 4A). The immunolabeling described here was specific because it was absent in Kv3.1 or Kv3.2 KO mice (Fig. 4, bottom panels).
Expression of Kv3.1 and Kv3.2 proteins in starburst amacrine cells

The pattern described above suggests that Kv3.1 and Kv3.2 proteins are expressed in the somata of starburst amacrine cells and dendritic processes. To confirm this, we performed double-staining immunohistochemistry with markers for starburst cells. Kv3.1b and Kv3.2 staining overlapped with that of calbindin and calretinin in starburst cell somata and dendritic processes (Gabriel and Witkovsky, 1998; Haverkamp and Wässle 2000) (data not shown). Because starburst cells are cholinergic (Masland and Mills, 1979; Famiglietti, 1983), they can be labeled by antibodies against ChAT, the synthesizing enzyme of acetylcholine. Double-labeling experiments in mouse retina confirmed that Kv3.1 and Kv3.2 proteins are expressed in ChAT-labeled starburst cell somata and dendritic processes (Fig. 5). The Kv3.1b and Kv3.2 antibodies produced a similar staining pattern of starburst cell somata and dendrites in sections of rabbit retina (data not shown).

To examine the extent of the expression of $\mathrm{Kv} 3$ proteins in starburst cells, we stained whole-mount mouse retinas with Kv3.1b antibodies and imaged sections at different optical depths. Prominent membrane staining of small somata was observed in the GCL and again in proximal INL (Fig. 6). Dual labeling experiments with antibodies to ChAT and Kv3 protein showed that virtually all of the small cells that were positive for $\mathrm{Kv} 3.1 \mathrm{~b}$ (Fig. 7) and/or Kv3.2 (data not shown) were positive for ChAT and, likewise, virtually all of the ChAT-positive neurons in these layers were positive for $\mathrm{Kv} 3.1 \mathrm{~b}$ and $\mathrm{Kv} 3.2$.

In addition, a dense plexus of dendritic processes was revealed with confocal optical sectioning, showing immunolabeling throughout the arbors of both starburst-a and starburst-b amacrine cells (Fig. 6). In this flat-mount material, it appeared that somata and/or proximal dendritic segments were more brightly labeled. To confirm this, we were able to find areas within our material in which, fortuitously, single dendrites could be followed from their somatic origins to distal terminal zones. Figure $8 B$ illustrates a z-stack of 10 optical planes of section ( $0.5 \mu \mathrm{m}$ thick) showing Kv3.1b immunolabeling of a single starburst cell dendrite. Although the proximal, intermediate, and distal dendritic zones are all labeled, it is clear that the soma and proximal dendritic processes display the brightest labeling. For comparison, we show the labeling pattern of a starburst cell filled with Neurobiotin, in which, despite the fact that the tracer was injected into the soma, it is the 

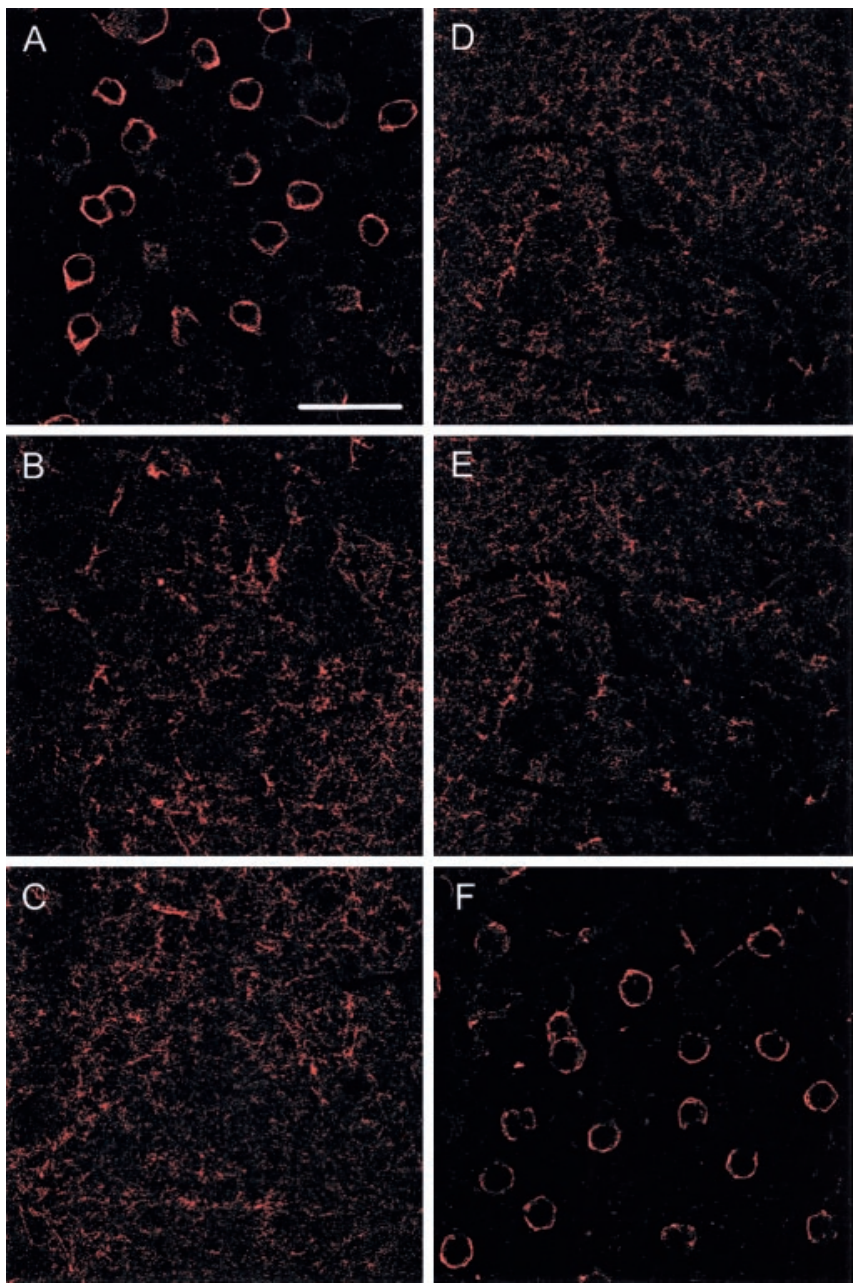

Figure 6. Expression of Kv3.1b in starburst amacrine cell somata and dendritic processes. $A-F$, Family of z-stacked confocal images ( $0.5 \mu \mathrm{m}$ thick) showing Kv3.1b immunostaining in a whole-mount retina preparation at different optical levels from the $G C L$ to the INL. Somata $(A$, $F)$ and processes of starburst amacrine cells ( $B-E)$ display Kv3.1b immunoreactivity. However, distal processes of both starburst- $b(C)$ and starburst-a $(D)$ cells show reduced labeling intensity. Scale bar, $20 \mu \mathrm{m}$.

distal dendritic processes that are brightest because of the greater membrane surface area (Fig. $8 D$ ). Thus, the gradient of Kv3 labeling we found is opposite to that expected simply on surface area distribution of dendritic membrane. A drawing of a single starburst cell dendrite is provided (Fig. 8A) as a reference to the different regions and to show that the distal dendritic segments of these cells are relatively thicker than proximal branches and thus have greater membrane surface area (Miller and Bloomfield, 1983; Poznanski, 1992; Farajian et al., 2004).

To quantify any regional variation in immunolabeling of the dendrite, we used NIH Image software to determine the average intensity of label within each segment of a starburst cell (Fig. 8C). This analysis, performed on six dendrites from six different cells, indicated that although the somatic and proximal dendritic membranes showed approximately equal intensity of immunolabeling, there was a statistically significant reduction in the intensity of labeling in the intermediate and distal regions, despite the latter's relatively greater membrane surface area. These results suggest a gradient in the distribution of Kv3 channels within the arbor of starburst cell dendrites, which, in turn, may have dramatic affects on the propagation of synaptic currents (see Discussion).

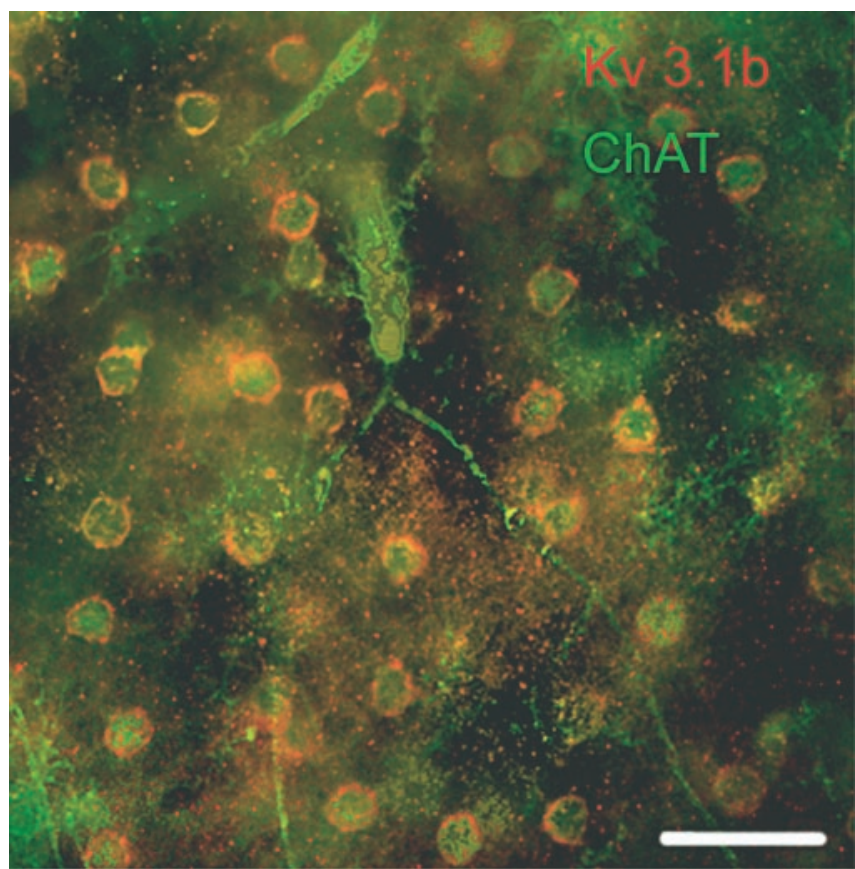

Figure 7. Kv3.1b is expressed in all starburst cells. A flat-mount image of a WT mouse retina is shown, focusing on the plane of the INL, double stained with Kv3.1b (Cy3) and ChAT (FITC) antibodies. Note that all ChAT-positive cells show membrane labeling of Kv3.1b. Scale bar, $20 \mu \mathrm{m}$.

The Kv3-like current in starburst cells is mediated by channels containing Kv3.1-Kv3.2 proteins

The recordings described above showed that the majority of the outward current in starburst cells has electrophysiological and pharmacological properties characteristic of currents mediated by Kv3 channels. Consistent with this hypothesis, immunohistochemical methods demonstrated the presence of Kv3.1 and Kv3.2 proteins in these cells. To confirm that the majority of the $\mathrm{K}^{+}$ current in starburst cell somata is carried by channels containing these proteins, we compared the currents in starburst cells from Kv3.1-Kv3.2 double knock-out mice with the currents observed in cells from WT litter mates. Compared with WT controls, starburst amacrine cells in Kv3.1-Kv3.2 knock-out mice had significantly smaller outward currents $(80.2 \pm 23.7 \mathrm{pA} / \mathrm{pF}, n=6$ cells, vs $231.4 \pm 25.0 \mathrm{pA} / \mathrm{pF}, n=10$ cells, at $+50 \mathrm{mV}$ ), which deactivated more slowly (Fig. 9A,B). Furthermore, consistent with the suggestion that Kv3 currents limit the depolarization of these cells in response to current injection, outward rectification was significantly weaker in neurons from DKO mice (Fig. 9C,D).

\section{Discussion}

Our data demonstrate that starburst amacrine cells in the mouse retina have large outward currents, most of which are mediated by the Kv3 subfamily of $\mathrm{K}^{+}$channels. This group of voltage-gated $\mathrm{K}^{+}$channels has several distinctive properties, including fast activation during membrane depolarization, very fast closing (or deactivation) after repolarization, and a positively shifted voltage dependence when compared with other subfamilies of voltagegated $\mathrm{K}^{+}$channels (Rudy et al., 1999; Rudy and McBain, 2001). These channel properties are thought to allow the fast repolarization of action potentials and the production of deep, brief afterhyperpolarizations, thereby facilitating faithful repetitive firing at high frequencies (Wang et al., 1998; Erisir et al., 1999; Rudy and McBain, 2001; Lien and Jonas, 2003). 


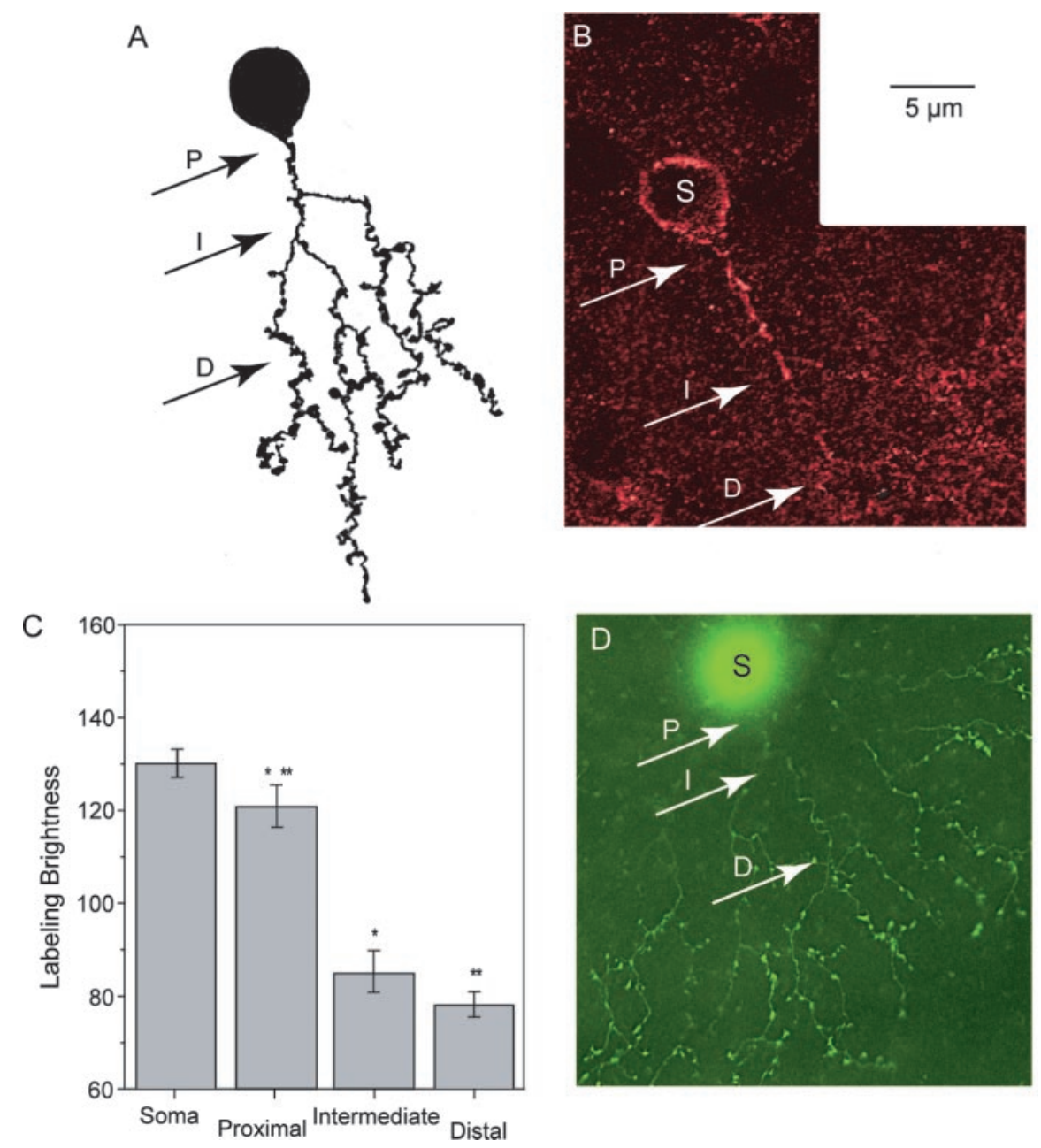

Figure 8. Localization of Kv3.1b in starburst amacrine cell dendrites shows a proximal-distal gradient. A, Schematic showing the soma and a single dendrite of a starburst amacrine cell. Arrows point to the start of different zones of the dendritic arbor ( $P$, primary dendrite; I, intermediate dendrites; D, distal dendrites). B, A z-stack of 10 optical planes (0.5- $\mu$ m-thick) of confocal images was used to trace the intensity of Kv3.1b immunolabel along a single dendrite of a starburst amacrine cell. Although $P, I$, and $D$ dendritic zones are all labeled, the intensity of Kv3.1b immunolabel shows a sequential decrement from proximal to distal zones. C, Histogram showing the averaged brightness intensity of the Kv3.1b immunolabeling in the four dendritic zones on a $0-255$ scale. Data are from six starburst cell dendrites from six different cells. Error bars represent SEM. Symbols indicate statistical significant differences $(p<0.001$ ). Bars with same symbols are compared. $D$, Dendritic arbor of a starburst cell injected intracellularly with Neurobiotin. Note that the dendritic branches in the distal zone are more brightly labeled than proximal branches caused by the greater membrane surface area. S, Soma.

Expression of Kv3 proteins in starburst cell dendrites

With the exception of a very few ganglion cells, starburst amacrine cells were found to uniquely express Kv3.1 and Kv3.2 protein in the mouse retina. In most Kv3.1- and Kv3.2-expressing neurons, the protein is localized in somatic and axonal membranes, with little expression in dendrites other than their initial segments (Moreno et al., 1995; Weiser et al., 1995; Du et al., 1996; Sekirnjak et al., 1997; Chow et al., 1999). It is clear that the axonless starburst cells represent an unusual distribution of Kv3 subunits within the soma and dendritic processes. In this way, starburst cells resemble the mitral cells of the olfactory bulb in which Kv3.1 proteins are also prominently expressed throughout the dendritic arbor (Ozaita et al., 2002). Interestingly, mitral and starburst cell dendrites are unusual in having both a dendritic and an axonal character. In both cell types, dendrites participate in reciprocal dendrodendritic synapses, release neurotransmitter, and contain presynaptic vesicles and other elements of presynaptic terminals (Rall et al., 1966; Brandon, 1987; Famiglietti, 1991;
Isaacson and Strowbridge, 1998; Shepherd and Greer, 1998). Therefore, these dendrites must have the molecular machinery necessary for the trafficking and retention of axonal proteins. However, the functional role of the $\mathrm{Kv} 3$ channels is probably different in the two cell types. In mitral cell dendrites, which display powerful $\mathrm{K}^{+}$currents (Bischofberger and Jonas, 1997), Kv3 channels probably facilitate the faithful backpropagation of spike trains (Ozaita et al., 2002). This role is more akin to that of somatic Kv3 channels in facilitating faithful high-frequency repetitive firing and different from that suggested below for $\mathrm{Kv} 3$ channels in starburst cells. Although it is still controversial whether starburst amacrine cells in the adult retina have the ability to produce action potentials (Bloomfield, 1992; Taylor and Wässle, 1995; Peters and Masland, 1996; Zhou and Fain, 1996; Cohen, 2001; Gavrikov et al., 2003), they are clearly not repetitive firing neurons, indicating that Kv3 channels play a novel role in these cells.

\section{Role of Kv3 channels in starburst} amacrine cells

If Kv3 channels do not support repetitive spiking in starburst cells, then what is their role? Clearly, their function must be important to starburst cell physiology in that Kv3 currents represent the most prominent outward current in these cells. As a major presynaptic element in the circuitry subserving DS ganglion cells, starburst cells have long been implicated as playing a crucial role in generating direction selectivity in the retina. Indeed, it was shown recently that starburst cells form asymmetric synaptic contacts onto DS cells that provide the GABAergic null inhibition critical to their direction selectivity (Fried et al., 2002). Moreover, the GABAergic inhibition provided by starburst cells is itself direction selective. Two properties intrinsic to starburst cells appear to play a major role in creating their direction-selective inhibitory responses. First, voltage attenuation in the centripetal direction electrically isolates dendrites whereby single starburst cell dendrites can perform single computations independently and simultaneously (Miller and Bloomfield, 1983; Euler et al., 2002). Second, two-photon $\mathrm{Ca}^{2+}$ imaging indicates that a single dendrite responds better to light moving centrifugally then centripetally, thereby providing a mechanism for the direction selectivity of their inhibitory output (Euler et al., 2002). We suggest that Kv3 channels may play a role in generating both of these intrinsic properties.

In the computational model in the study by Miller and Bloomfield (1983), the electrical independence of individual starburst dendrites was a consequence of the unusually thin caliber of the proximal dendritic segments. However, subsequent modeling studies indicated that the electrical isolation of dendrites in starburst cells depends on assumptions of either relatively low 
A

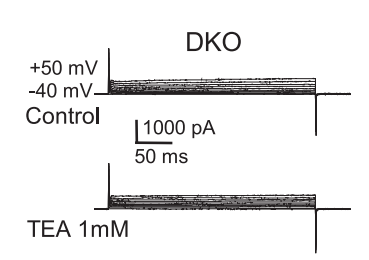

TEA sensitive

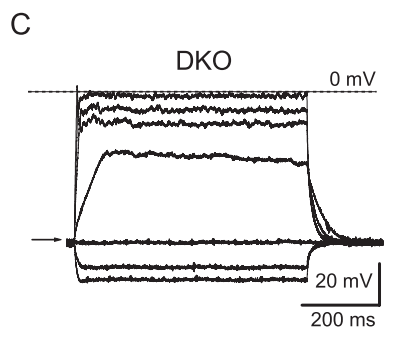

B
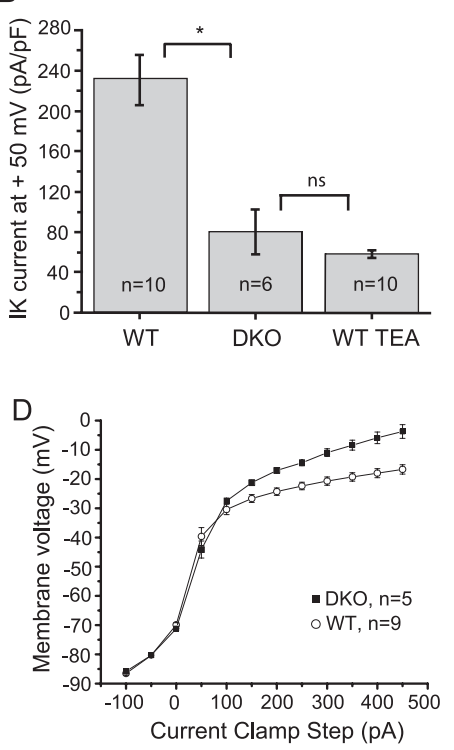

Figure 9. Kv3-like currents are absent in starburst cells from Kv3.1-Kv3.2 knock-out (DKO) animals. $A$, Membrane currents recorded in a starburst cell from a DKO mouse after voltageclamp steps ranging from -40 to $+50 \mathrm{mV}$ (in $10 \mathrm{mV}$ steps) in control solution (top panel) and in the presence of $1 \mathrm{~mm}$ TEA (middle panel). The TEA-sensitive current obtained by subtraction is shown in the bottom panel. Note the low amplitude of the currents when compared with WT (Fig. 2A). B, Histogram comparing outward current density (at $+50 \mathrm{mV}$ ) for cells from WT and DKO animals in the presence and absence of TEA. Error bars represent SEM. The asterisk indicates statistically significant difference between WT and DKO cells $(p<0.001)$. The average values for DKO cells and WT cells in the presence of TEA were not statistically different ( $n s ; p=0.249$ ). C, Steps of current were injected in a starburst amacrine cell from a DKO mouse for $600 \mathrm{msec}$, and resulting membrane voltage responses were recorded under whole-cell patch clamp. Between pulses, the cell was maintained at a voltage of $-70 \mathrm{mV}$ by constant injection of a small amount of current (indicated by the arrow at the left of the traces). The voltage traces are in response to injection of current pulses of $-100,-50,0,+50,+200,+300$, and $+400 \mathrm{pA}$. The dotted line represents $0 \mathrm{mV}$. Note the shift toward more depolarized potentials in the DKO compared with WT (Fig. 1A).D, Relationship between membrane voltage and injected current of starburst amacrine cells in WT and DKO mice. Note the decrease in outward rectification in DKO. Error bars represent SEM.

specific membrane resistance or minimal synaptic coactivation of individual dendrites (Poznanski, 1992; Velte and Miller, 1997). Our observation (illustrated in Figure 1) that it was difficult to depolarize starburst cell somata beyond $-20 \mathrm{mV}$ suggests that Kv3 currents generate a voltage-dependent shunt located proximally, which prevents effective depolarization of the starburst cell soma. This shunt could provide a mechanism by which the dendrites of the starburst cell maintain electrical independence. In this scenario, centripetal movement of synaptic current would be shunted and attenuated in the proximal soma-dendritic region whereby signals would be prevented from reaching adjacent proximal dendrites.

The somatic shunt that we found is consistent with the variability in the brightness of immunolabeling, suggesting a gradient in the density of $\mathrm{Kv} 3 \mathrm{~K}^{+}$channels with soma = primary dendrites $>$ intermediate dendrites $>$ distal dendrites. Because of the dense plexus of labeled processes in our material, we were unable to normalize differences in staining intensities to total available membrane, which will be necessary to demonstrate unequivocally that there is a gradient of Kv3 channels in individual starburst cells. However, as illustrated in Figure 8, starburst cells have a unique morphology in which the caliber of distal dendrites is greater than that of proximal branches, meaning that dendritic membrane surface area will also be greater in the periphery. Thus,

if Kv3 channel density was uniform across the starburst cell dendritic arbor, we would have expected to find brighter immunolabeling in the distal regions because of the greater membrane surface area. Our finding that proximal regions displayed brighter immunolabeling not only suggests a proximally weighted gradient in Kv3 channel density but, taking into account the opposing change in membrane surface area, it is likely that our data actually underestimate the extent of the gradient.

The gradient in Kv3 channel density may also play a role in the starburst cell preference for centrifugal stimulus movement reported by Euler at al. (2002). It was proposed that as a stimulus moves centrifugally across a starburst cell dendrite, it first produces excitatory synaptic potentials that propagate distally. These signals, resulting from a temporal delay, then arise at peripheral branches and can summate with synaptic potentials generated there by the arriving moving stimulus, resulting in a relatively large release of GABA from presynaptic sites that are restricted to the distal branches. In contrast, a stimulus moving centripetally would stimulate peripheral branches first, eliciting a GABA release, but summation occurring more centrally would not cause an additional GABA release, because there are no output synapses found on the intermediate or proximal dendrites. However, Euler et al. (2002) discounted this model because they did not find evidence of summation at proximal sites with centripetal stimulus movement. Our results suggest that the relatively high density of Kv3 channels found proximally would serve to shunt centripetal currents and thus could explain the failure to see summation at central sites. Thus, the proximal weighting of Kv3 channels would serve to electrically isolate individual dendrites and oppose summing of synaptic signals produced by centripetal, but not centrifugal, moving stimuli.

Overall, our hypothesis predicts that Kv3 channels play a role in generating the two intrinsic properties of starburst cells crucial to the generation of direction selectivity. It will of course be of interest to test this idea using Kv3.1/3.2 knock-out mice. We predict that loss of Kv3 channels will compromise the electrical isolation of starburst cell dendrites and their difference in signaling centrifugal versus centripetal moving stimuli, thereby impairing asymmetric GABA release and the direction-selective signaling of the postsynaptic ganglion cells.

\section{References}

Amthor FR, Keyser KT, Dmitrieva NA (2002) Effects of the destruction of starburst-cholinergic amacrine cells by the toxin AF64A on rabbit retinal directional selectivity. Vis Neurosci 19:495-509.

Ariel M, Daw NW (1982) Pharmacological analysis of directionally sensitive rabbit retinal ganglion cells. J Physiol (Lond) 324:161-185.

Barlow HB, Levick WR (1965) Mechanism of directionally selective units in rabbits retina. J Physiol (Lond) 178:477-504.

Barlow HB, Hill RM, Levick WR (1964) Retinal ganglion cells responding selectively to direction and speed of image motion in the rabbit. J Physiol (Lond) 173:377-407.

Bischofberger J, Jonas P (1997) Action potential propagation into the presynaptic dendrites of rat mitral cells. J Physiol (Lond) 504:359-365.

Bloomfield SA (1992) Relationship between receptive and dendritic field size of amacrine cells in the rabbit retina. J Neurophysiol 68:711-725.

Bloomfield SA, Miller RF (1986) A functional organization of ON and OFF pathways in the rabbit retina. J Neurosci 6:1-13.

Brandon C (1987) Cholinergic neurons in the rabbit retina: dendritic branching and ultrastructural connectivity. Brain Res 426:119-130.

Caldwell JH, Daw NW, Wyatt HJ (1978) Effects of picrotoxin and strychnine on rabbit retinal ganglion cells: lateral interactions for cells with more complex receptive fields. J Physiol (Lond) 276:277-298.

Chow A, Erisir A, Farb C, Nadal MS, Ozaita A, Lau D, Welker E, Rudy B (1999) $\mathrm{K}^{+}$channel expression distinguishes subpopulations of 
parvalbumin- and somatostatin-containing neocortical interneurons. J Neurosci 19:9332-9345.

Cohen ED (2001) Voltage-gated calcium and sodium currents of starburst amacrine cells in the rabbit retina. Vis Neurosci 18:799-809.

Du J, Zhang L, Weiser M, Rudy B, McBain CJ (1996) Developmental expression and functional characterization of the potassium-channel subunit Kv3.1b in parvalbumin-containing interneurons of the rat hippocampus. J Neurosci 16:506-518.

Erisir A, Lau D, Rudy B, Leonard CS (1999) Function of specific K(+) channels in sustained high-frequency firing of fast-spiking neocortical interneurons. J Neurophysiol 82:2476-2489.

Euler T, Detwiler PB, Denk W (2002) Directionally selective calcium signals in dendrites of starburst amacrine cells. Nature 418:845-852.

Famiglietti EV (1983) "Starburst" amacrine cells and cholinergic neurons: mirror-symmetric on and off amacrine cells of rabbit retina. Brain Res 261:138-144.

Famiglietti EV (1991) Synaptic organization of starburst amacrine cells in rabbit retina: analysis of serial thin sections by electron microscopy and graphic reconstruction. J Comp Neurol 309:40-70.

Famiglietti EV (1992) Dendritic co-stratification of ON and ON-OFF directionally selective ganglion cells with starburst amacrine cells in rabbit retina. J Comp Neurol 324:322-335.

Farajian R, Raven MA, Cusato K, Reese BE (2004) Cellular positioning and dendritic field size of cholinergic amacrine cells are impervious to early ablation of neighboring cells in the mouse retina. Vis Neurosci 21:13-22.

Fried SI, Munch TA, Werblin FS (2002) Mechanisms and circuitry underlying directional selectivity in the retina. Nature 420:411-414.

Gabriel R, Witkovsky P (1998) Cholinergic, but not the rod pathway-related glycinergic (All), amacrine cells contain calretinin in the rat retina. Neurosci Lett 247:179-182.

Gavrikov KE, Dmitriev AV, Keyser KT, Mangel SC (2003) Cation-chloride cotransporters mediate neural computation in the retina. Proc Natl Acad Sci USA 100:16047-16052.

Hartshorne RP, Catterall WA (1984) The sodium channel from rat brain. Purification and subunit composition. J Biol Chem 259:1667-1675.

Haverkamp S, Wässle H (2000) Immunocytochemical analysis of the mouse retina. J Comp Neurol 424:1-23.

He S, Masland RH (1997) Retinal direction selectivity after targeted laser ablation of starburst amacrine cells. Nature 389:378-382.

Ho CS, Grange RW, Joho RH (1997) Pleiotropic effects of a disrupted K+ channel gene: reduced body weight, impaired motor skill and muscle contraction, but no seizures. Proc Natl Acad Sci USA 94:1533-1538.

Hu EH, Dacheux RF, Bloomfield SA (2000) A flattened retina-eyecup preparation suitable for electrophysiological studies of neurons visualized with trans-scleral infrared illumination. J Neurosci Methods 103:209-216.

Isaacson JS, Strowbridge BW (1998) Olfactory reciprocal synapses: dendritic signaling in the CNS. Neuron 20:749-761.

Kittila CA, Massey SC (1995) The effect of ON pathway blockade on directional selectivity in rabbit retina. J Neurophysiol 73:703-712.

Lau D, Vega-Saenz de Miera EC, Contreras D, Ozaita A, Harvey M, Chow A, Noebels JL, Paylor R, Morgan JI, Leonard CS, Rudy B (2000) Impaired fast-spiking, suppressed cortical inhibition, and increased susceptibility to seizures in mice lacking $\mathrm{Kv} 3.2 \mathrm{~K}^{+}$channel proteins. J Neurosci 20:9071-9085.

Lien CC, Jonas P (2003) Kv3 potassium conductance is necessary and kinetically optimized for high-frequency action potential generation in hippocampal interneurons. J Neurosci 23:2058-2068.

Masland RH, Ames A (1976) Responses to acetylcholine of ganglion cells in an isolated mammalian retina. J Neurophysiol 39:1220-1235.

Masland RH, Mills JW (1979) Autoradiographic identification of acetylcholine in the rabbit retina. J Cell Biol 83:159-178.
Miller RF, Bloomfield SA (1983) Electroanatomy of a unique amacrine cell in the rabbit retina. Proc Natl Acad Sci USA 80:3069-3073.

Moreno H, Kentros C, Bueno E, Weiser M, Hernandez A, Vega-Saenz de Miera E, Ponce A, Thornhill W, Rudy B (1995) Thalamocortical projections have $\mathrm{K}^{+}$channel that is phosphorylated and modulated by cAMPdependent protein kinase. J Neurosci 15:5486-5501.

Nicoll RA (1969) Inhibitory mechanisms in the rabbit olfactory bulb: dendrodendritic mechanisms. Brain Res 14:157-172.

Ozaita A, Martone ME, Ellisman MH, Rudy B (2002) Differential subcellular localization of the two alternatively spliced isoforms of the Kv3.1 potassium channel subunit in brain. J Neurophysiol 88:394-408.

Peters BN, Masland RH (1996) Responses to light of starburst amacrine cells. J Neurophysiol 75:469-480.

Poznanski RR (1992) Modelling the electrotonic structure of starburst amacrine cells in the rabbit retina: a functional interpretation of dendritic morphology. Bull Math Biol 54:905-928.

Rall W, Shepherd GM, Reese TS, Brightman MW (1966) Dendrodendritic synaptic pathway for inhibition in the olfactory bulb. Exp Neurol 14:44-56.

Rudy B, McBain CJ (2001) Kv3 channels: voltage-gated $\mathrm{K}^{+}$channels designed for high-frequency repetitive firing. Trends Neurosci 24:517-526.

Rudy B, Chow A, Lau D, Amarillo Y, Ozaita A, Saganich M, Moreno H, Nadal MS, Hernandez-Pineda R, Hernandez-Cruz A, Erisir A, Leonard C, VegaSaenz de Miera E (1999) Contributions of Kv3 channels to neuronal excitability. Ann NY Acad Sci 868:304-343.

Sekirnjak C, Martone ME, Weiser M, Deerinck T, Bueno E, Rudy B, Ellisman M (1997) Subcellular localization of the $\mathrm{K}^{+}$channel subunit Kv3.1b in selected rat CNS neurons. Brain Res 766:173-187.

Shepherd GM, Greer CA (1998) Olfactory bulb. In: The synaptic organization of the brain, Ed 4 (Shepherd GM, ed), pp 159-204. New York: Oxford UP.

Tansey EP, Chow A, Rudy B, McBain CJ (2002) Developmental expression of potassium-channel subunit Kv3.2 within subpopulations of mouse hippocampal inhibitory interneurons. Hippocampus 12:137-148.

Tauchi M, Masland RH (1984) The shape and arrangement of the cholinergic neurons in the rabbit retina. Proc $\mathrm{R}$ Soc Lond B Biol Sci 223:101-119.

Taylor WR, Wässle H (1995) Receptive field properties of starburst cholinergic amacrine cells in the rabbit retina. Eur J Neurosci 7:2308-2321.

Vaney DI, Collin SP, Young HM (1989) Dendritic relationships between cholinergic amacrine cells and direction-selective retinal ganglion cells. In: Neurobiology of the inner retina, Vol H31 (Weiler R, Osborne NN, eds), pp 157-168. Berlin: Springer.

Velte TJ, Miller RF (1997) Spiking and nonspiking models of starburst amacrine cells in the rabbit retina. Vis Neurosci 14:1073-1088.

Wang LY, Gan L, Forsythe ID, Kaczmarek LK (1998) Contribution of the Kv3.1 potassium channel to high-frequency firing in mouse auditory neurons. J Physiol (Lond) 509:183-194.

Weiser M, Vega-Saenz de Miera E, Kentros C, Moreno H, Franzen L, Hillman D, Baker H, Rudy B (1994) Differential expression of Shaw-related $\mathrm{K}^{+}$ channels in the rat central nervous system. J Neurosci 14:949-972.

Weiser M, Bueno E, Sekirnjak C, Martone ME, Baker H, Hillman D, Chen S, Thornhill W, Ellisman M, Rudy B (1995) The potassium channel subunit KV3.1b is localized to somatic and axonal membranes of specific populations of CNS neurons. J Neurosci 5:4298-4314.

Wyatt HJ, Daw NW (1976) Specific effect of neurotransmitter antagonists on ganglion cells in rabbit retina. Science 191:204-205.

Yoshida K, Watanabe D, Ishikane H, Tachibana M, Pastan I, Nakanishi S (2001) A key role of starburst amacrine cells in originating retinal directional selectivity and optokinetic eye movement. Neuron 30:771-780.

Zhou ZJ, Fain GL (1996) Starburst amacrine cells change from spiking to nonspiking neurons during retinal development. Proc Natl Acad Sci USA 93:8057-8062. 